\title{
Moringa oleifera: bioactive compounds and nutritional potential
}

\author{
Moringa oleifera: compostos bioativos \\ e potencialidade nutricional
}

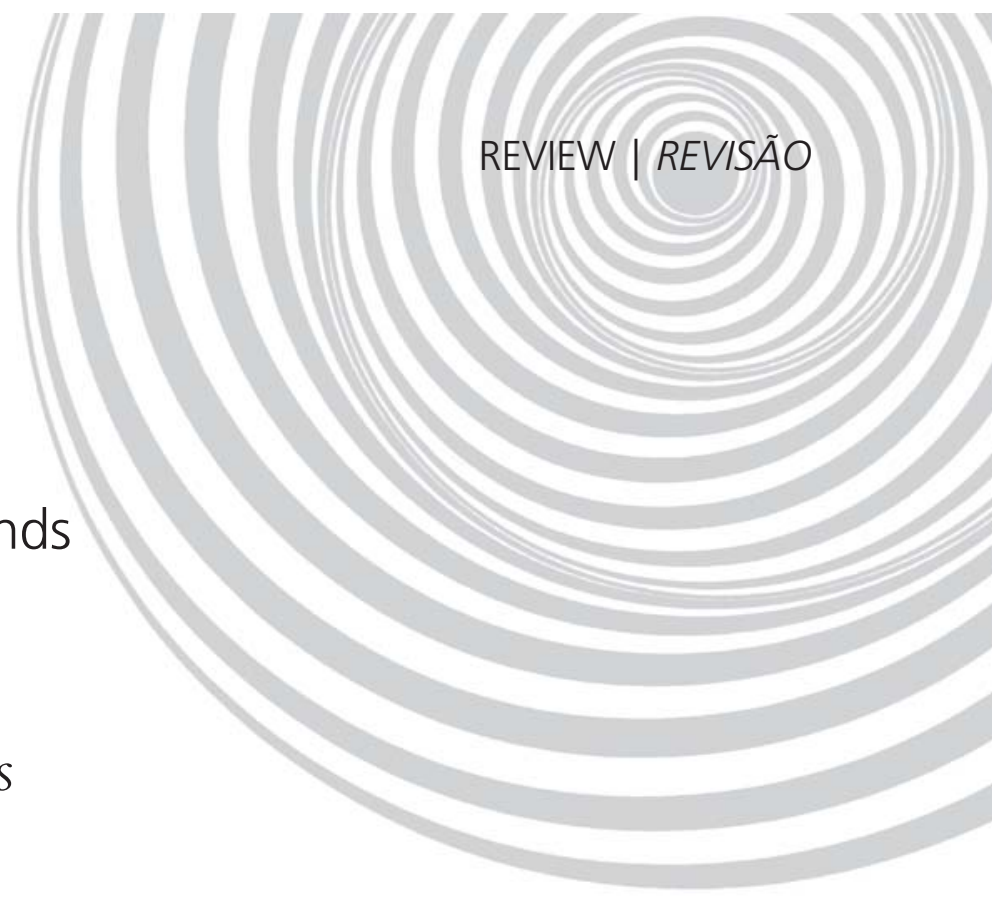

Paulo Michel Pinheiro FERREIRA'

Davi Felipe FARIAS²

José Tadeu de Abreu OLIVEIRA²

Ana de Fátima Urano CARVALHO ${ }^{3}$

\begin{abstract}
A B S T R A C T
This work aims to review the nutritional properties of the Moringa oleifera tree, emphasizing its main constituents and nutritional applications for humans and animals. Moringa oleifera (Moringaceae) is a cosmopolitan tree that grows in many tropical countries showing uncountable folk uses due to its various nutritional and pharmacological applications. The young leaves, flowers and pods are common vegetables in the Asian diet. All parts of this plant are renewable sources of tocopherols ( $\gamma$ and $\alpha$ ), phenolic compounds, B-carotene, vitamin C and total proteins, including the essential sulfur amino acids, methionine and cysteine. The seed protein and fat contents are higher than those reported for important grain legumes and soybean varieties, respectively. Unsaturated fatty acids, especially oleic acid, carbohydrates and minerals are present in the seed in reasonable amounts. In general, there are low concentrations of antinutritional factors in the plant, although the seeds possess glucosinolates $(65.5 \mu \mathrm{mol} / \mathrm{g}$ dry matter $)$, phytates $(41 \mathrm{~g} / \mathrm{kg})$ and hemagglutination activity while the leaves have appreciable amounts of saponins $(80 \mathrm{~g} / \mathrm{kg})$, besides low quantity of phytates $(21 \mathrm{~g} / \mathrm{kg})$ and tannins $(12 \mathrm{~g} / \mathrm{kg})$. Taking into consideration the excellent nutritional properties, the low toxicity of the seeds and the excellent ability of the plant to adapt to poor soils and dry climates, Moringa oleifera can be an alternative to some leguminous seeds as a source of high-quality protein, oil and antioxidant compounds and a way to treat water in rural areas where appropriate water resources are not available.
\end{abstract}

Indexing terms: Protease Inhibitors. Moringa oleifera. Nutritive value.

RE S U M O

O objetivo deste trabalho é fazer uma revisão sobre as propriedades nutricionais da planta Moringa oleifera, enfatizando seus principais constituintes e suas aplicações nutricionais para o homem e os animais. Moringa

${ }^{1}$ Universidade Federal do Ceará, Faculdade de Medicina, Departamento de Fisiologia e Farmacologia. Fortaleza, CE, Brasil.

2 Universidade Federal do Ceará, Departamento de Bioquímica e Biologia Molecular. Fortaleza, CE, Brasil.

3 Universidade Federal do Ceará, Departamento de Biologia. Av. Mister Hall, s/n., Campus do Pici, 60455-970, Fortaleza, CE, Brasil. Correspondence to/Correspondência para: A.F.V. CARVALHO.E-mail: <aurano@ufc.br>. 
oleifera é uma planta que cresce em muitos países tropicais, possuindo inúmeros usos populares devido às suas aplicações nutricionais e farmacológicas. Na Ásia, suas folhas, flores e vagens são geralmente consumidas como vegetais. Todas as suas partes são fontes renováveis de compostos fenólicos, tocoferóis $(\gamma$ e $\alpha)$, B-caroteno, vitamina C e proteínas totais, inclusive os aminoácidos essenciais sulfurados metionina e cisteína. Os conteúdos de proteínas e óleo nas sementes de Moringa oleifera são mais elevados que aqueles encontrados em legumes e em algumas variedades de soja, respectivamente. Ácidos graxos insaturados, principalmente o ácido oléico, carboidratos e minerais estão presentes nas sementes em quantidades razoáveis. No geral, a planta possui baixas concentrações de fatores antinutricionais, embora as sementes possuam glucosinolatos $(65,5 \mu \mathrm{mol} / \mathrm{g})$, fitatos $(41 \mathrm{~g} / \mathrm{kg})$ e atividade hemaglutinante, enquanto as folhas têm apreciáveis quantidades de saponinas $(80 \mathrm{~g} / \mathrm{kg})$, além de fitatos $(21 \mathrm{~g} / \mathrm{kg})$ e taninos $(12 \mathrm{~g} / \mathrm{kg})$. Levando em consideração as excelentes propriedades nutricionais, a baixa toxicidade das sementes e a excelente habilidade da planta de se adaptar a solos pobres e a climas áridos, a Moringa oleifera pode ser uma alternativa ao consumo de sementes leguminosas, como fonte de proteínas de alta qualidade, de óleo e de compostos antioxidantes. Pode ser usada, ainda, como uma maneira de tratar água em áreas rurais onde recursos hídricos adequados não estão disponíveis.

Termos de indexação: Inibidores de proteases. Moringa oleifera. Valor nutritivo.

\section{INTRODUCTION}

Moringa oleifera Lamarck (synonym: Moringa pterygosperma Gaertner) is a South Asian tree belonging to the Moringaceae family that grows near The Himalaya mountains, from Northwest Pakistan to North India'. The tree is deciduous, growing rapidly even in poor soils, well adapted to droughts and able to reach up to $15 \mathrm{~m}$ in height, with a diameter of $20-40 \mathrm{~cm}$ at chest height. It produces dry fruits, triangular in shape, making seed dispersion by the wind easier ${ }^{2}$. It has been introduced in many parts of the world, like Afghanistan, Bangladesh, Sri Lanka, Africa, West Asia and in the Americas, from Mexico to Peru, Caribbean Islands, Paraguay and Brazil ${ }^{3-5}$.

The species M. oleifera is known worldwide by several popular names such as "resedá", "árbol de rábano", horseradish tree, drumstick tree, "ângela", "árbol de los espárragos", white-lily, "quiabo de quina" and many others ${ }^{1,5}$.

Extracts from all parts of the plant show pharmacological properties, recognized by popular use and corroborated by the scientific community. Leaf extracts show hypocholesterolaemic ${ }^{6}$, hypotensive, bradycardic ${ }^{7}$ and anti-ulcerative activity $^{8}$. The dry pods are adequate to use as a substratum for laboratory animal bedding 9 . The seeds show antimicrobial activity against fungi $i^{10,11}$ and bacteria ${ }^{10,12,13}$, antitumor ${ }^{14}$, anti-inflammatory, antispasmodic, diuretic ${ }^{15}$ and larvicidal activity against the mosquito that transmits dengue and yellow fever ${ }^{16}$. Gupta et al. ${ }^{17}$ showed that the roots were able to depress the central nervous system, cause analgesia and potentiate the analgesic effect of morphine.

This article aims to review the nutritional properties of the Moringa oleifera tree, emphasizing its main constituents and nutritional applications for humans and animals.

\section{Bioactive compounds}

In Asia, the flowers of $M$. oleifera are mixed together with other foods since they are rich in $\mathrm{Ca}^{2+}, \mathrm{K}^{+}$, waxes, alkaloids, quercetin and kaempferol ${ }^{1,18}$. Quercetin and kaempferol are flavonoids, compounds with phenolic hydroxyl groups with antioxidant action that have potential therapeutic uses ${ }^{19}$. In vitro studies have shown that quercetin and other flavonoids strongly inhibit the production of both nitric oxide and tumor necrosis factor by Kupffer cells when stimulated by injury ${ }^{20}$. Flavonoids protect the cells against injury caused by X-rays, block the progression of the cell cycle and prostaglandin synthesis, inhibit mutations and prevent carcinogenesis in experimental animals ${ }^{21}$.

A high content of $\gamma$-tocopherol has been found in practically the whole plant, ranging from $5.7 \mu \mathrm{g} / \mathrm{g}$ (adult leaves) to $27.8 \mu \mathrm{g} / \mathrm{g}$ (6 month-old leaves) of dry mass. Important variations have been encountered in $\alpha$-tocopherol values which ranged from $95.9 \mu \mathrm{g} / \mathrm{g}$ (green seeds) to $744.5 \mu \mathrm{g} / \mathrm{g}$ 
(adult plant leaves)22, differences probably explained by the variation between the age of the plants and their varied parts. Vitamin $\mathrm{E}$ is an antioxidant substance composed of tocopherols and $\alpha$-tocopherol is the most active and abundant constituent. This vitamin helps halt lipid peroxidation chain reactions generated by free radicals from cellular and subcellular membranes, which are rich in polyunsaturated lipids ${ }^{23}$. These antioxidant substances metabolize peroxides before they can cause any injury to cell membranes, maintaining the intracellular redox status ${ }^{24}$. Violation of this status favors oxidative stress, resulting in pathologic manifestations, such as atherosclerosis and cancer.

The leaves are used worldwide as a nutritional supplement as it contains significant amounts of vitamins $\mathrm{A}, \mathrm{B}$ and $\mathrm{C}$, plus $\mathrm{Ca}^{2+}, \mathrm{Fe}$ and proteins $\mathbf{s}^{1,25,26}$. Traces of carotenoids, mainly, B-carotene $(401 \mathrm{mg} / \mathrm{kg}$ of dry matter) and xanthins (neoxanthin $219 \mathrm{mg} / \mathrm{kg}$, violaxanthin $76.5 \mathrm{mg} / \mathrm{kg}$, zeaxanthin $19.4 \mathrm{mg} / \mathrm{kg}$ ) are also found ${ }^{27}$. In India and the Philippines, fresh leaves are used to preserve foods, probably due to the antioxidant substances $^{28}$. Besides its well established role in collagen synthesis, which prevents gingival bleeding and skin ecchymosis, characteristics of scurvy, vitamin $C$ can act as a scavenger of free radicals and indirectly regenerate vitamin $\mathrm{E}^{23}$. It is because of this synergism that both these vitamins have attracted interest as agents that can retard atherosclerosis by reducing low density lipoprotein (LDL) oxidation and thus limiting or even preventing injuries to vascular endothelial cells.

In Brazil, there have been efforts to divulge the plant as a rich source of vitamin A since the leaves contain approximately $23,000 \mathrm{IU}$ of this vitamin, much more than the traditional oily plants such as broccoli, carrot, kale, spinach and lettuce, which contain, respectively, 5,000, 3,700, 2,200, 1,900 and $1,000 \mathrm{IU}$ of vitamin $A^{29,30}$. Vitamin $A$ is important for normal vision in dim light, for the differentiation of mucus-secreting epithelium, preventing its keratinization ${ }^{23}$ and for host resistance against infections ${ }^{31}$.
In vivo radioprotective properties were demonstrated by methanolic extracts of dried leaves of $M$. oleifera, indicating that the leaves have a protective role against clastogenicity, evidently reducing chromosomal aberrations and micronuclei frequency in bone marrow cells ${ }^{32}$.

Bharali et al. ${ }^{14}$ showed that oral administration of a hydroalcoholic extract of $M$. oleifera green pods can increase liver levels of cytochrome $b_{5}$, cytochrome $P_{450}$, catalase and glutathione-peroxidase, reductase and S-transferase, enzymes involved in reactions of phases I and II that are responsible for the detoxification of xenobiotic substances, such as carcinogens and toxic plant compounds.

Epidemiologic studies have shown that population groups that consume high amounts of fruits and vegetables have a low risk of cancer. It has been postulated that carotenoids converted into vitamin $A$ in the liver and intestines, vitamins $C$ and $E$, sterols and selenium can have a relevant role in the primary chemoprevention of cancer by avoiding oxidative injury to DNA ${ }^{21}$.

\section{Nutritional potential}

M. oleifera leaves have essential amino acids, including the sulfur-containing amino acids in higher levels ${ }^{33}$ than those recommended by the Food and Agriculture Organization (FAO) ${ }^{34}$, with patterns similar to those of soybean seeds.

Analyses of the proximate composition of M. oleifera seeds have showed high levels of lipids and proteins (Table 1), with minor variations ${ }^{4,35}$. These variations may be explained by different climatic conditions, time of the year and different soil types from which the seeds were collected ${ }^{36}$. Abdulkarim et al. ${ }^{35}$ have described high levels of total proteins (383.0 standard deviation - SD=13.0g/ $\mathrm{kg}$ dry matter), which turned out to be greater than important leguminous seeds with respect to human nutrition, whose dry seeds usually contain 18 to $25 \%$ of protein, nearly double the contents of cereals ${ }^{36}$. 
Table 1. Proximate composition of Moringa oleifera seeds. From Brazil (1998) and India (2005).

\begin{tabular}{lccccc}
\hline \multirow{2}{*}{ Components } & \multicolumn{4}{c}{$\mathrm{g} / \mathrm{kg}$} \\
\cline { 2 - 3 } & \multicolumn{2}{c}{ Dry matter $^{\mathrm{c}}$} & & \multicolumn{2}{c}{ Dry matter $^{\mathbf{d}}$} \\
\cline { 2 - 3 } \cline { 5 - 6 } & $\mathrm{M}$ & $\mathrm{SD}$ & & $\mathrm{M}$ & $\mathrm{SD}$ \\
\hline Total Protein $^{\mathbf{a}}$ & 332.5 & 11.6 & & 383.0 & 13.0 \\
Lipid & 412.0 & 22.2 & & 308.0 & 21.9 \\
Carbohydrate & \multicolumn{2}{c}{211.2} & & \multicolumn{2}{c}{165.0} \\
Ash & 44.3 & 1.1 & & 45.0 & 3.8 \\
\hline
\end{tabular}

M: mean; SD: standard deviation; ${ }^{\text {a }} \mathrm{N} \times 6.25 ;{ }^{\text {b }}$ Calculated by difference; 'Oliveira et al. ${ }^{4}$; d Abdulkarim et al. ${ }^{35}$.

The seed lipid content (412.0 SD $=22.2 \mathrm{~g} /$ $\mathrm{kg}$ dry matter) reported by Oliveira et al. ${ }^{4}$ is greater than that of some soybean varieties (149-220g/ $\mathrm{kg} \mathrm{meal})^{37}$. The major saturated fatty acids present in the seeds are palmitic, stearic, arachidic and benic acids. Oleic acid is the main unsaturated fatty acid $(67.9-70.0 \%)^{35}$, whose high concentration is desirable in terms of nutrition and stability during cooking and frying. Moreover, as a natural source of benic acid, the $M$. oleifera seed oil has been used as a solidifying agent in margarines and other foodstuffs containing solid and semi-solid fat, therefore eliminating hydrogenation processes ${ }^{38}$. A lot of attention has been dedicated to oleic acid-rich plant oils, since an association has been established between diets rich in trans-unsaturated and saturated fatty acids and increased risk of cardiovascular diseases caused by high blood cholesterol levels ${ }^{39}$.

M. oleifera seed oil is highly resistant to oxidative rancification ${ }^{40}$, which can explain its several industrial uses such as in the production of cosmetics, machinery lubricants, cooking oil and fuel for lamps, being quite appreciated in the perfume industry due to its high odor retention capacity ${ }^{41}$.

Seed meal has high essential amino acid content, except for lysine (15.3g/kg protein), threonine $(30.8 \mathrm{~g} / \mathrm{kg})$ and valine $(43.5 \mathrm{~g} / \mathrm{kg})^{4}$, which are present in lower levels than those recommended for 2 to 5 -year-old children. The high methionine and cysteine $(43.6 \mathrm{~g} / \mathrm{kg}$ protein) contents are close to those of human and cow milk and chicken eggs ${ }^{34}$. With respect to the needs of a growing rat, lysine is the first limiting amino acid followed by isoleucine and leucine ${ }^{4}$. This abundance of essential amino acids encourages using the seeds as an excellent food substitute for legumes, which are usually poor in sulfur-containing amino acids.

In relation to antinutritional factors, leaves have a low quantity of tannins ( $12 \mathrm{~g} / \mathrm{kg}$ dry matter), phytates $(21 \mathrm{~g} / \mathrm{kg})$ and absence of trypsin and amylase inhibitors, lectins, cyanogenic glucosides and glucosinolates. Pods and stem contain irrelevant amounts of tannins but saponins and alkaloids are present in amounts biologically important in leaves $(80 \mathrm{~g} / \mathrm{kg}$ ) and stem, respectively, although in levels considered nontoxic to ruminants ${ }^{27,33}$. Soliva et al. ${ }^{42}$, using the Hohenheim gas test and the Rumen Simulation Technique, studied the effect on ruminal nitrogen turnover and fermentation of $M$. oleifera leaves in comparison with soybean and rapeseed meals. The high protein $(230 \mathrm{~g} / \mathrm{kg})$ content associated with high ruminal nitrogen degradability, good availability in the intestines and adequate levels of essential amino acids indicate the potential of M. oleifera leaves for ruminants fed tropical grasses, with about $95 \%$ of the total nitrogen in Moringa leaves being available either in the rumen or in the post rumen ${ }^{33,42}$. However, it is not known how these proteins arrive at the duodenum and how they would alter ruminant growth and milk composition.

In spite of being free of trypsin inhibitors and tannins, the seeds contain an acidic protein with hemagglutinating activity, glucosinolates $(65.5 \mu \mathrm{mol} / \mathrm{g})$ and phytates $(41 \mathrm{~g} / \mathrm{kg})^{4,16,33,43}$. Phytate contents of the kernel samples were higher than those in the vegetative parts ${ }^{27}$. Phytates present to an extent of $1 \%$ to $6 \%$ reduce mineral bioavailability in monogastric animals ${ }^{44}$, particularly, $\mathrm{Zn}^{2+}$ and $\mathrm{Ca}^{2+}$. Lectins, on the other hand, are usually responsible for agglutinating cells, interacting with intestinal epithelium, interfering with nutrient digestion and absorption and reducing food efficiency ${ }^{45}$.

The seed's bitter taste is generally attributed to alkaloids, saponins, cyanogenic glucosides and 
glucosinolates which are removed by treatment, suggesting that this taste would not limit the use of this material in animal diets. There is considerable genetic diversity between $M$. oleifera and $M$. stenopetal $a^{2}$, for example, and the literature shows that there are many different varieties whose kernels taste from sweet to very bitter. Seeds of some varieties are consumed by humans after roasting and taste like peanuts'. The amount of available protein for animal absorption in the seeds (62\%-69\%) may be greater than that of wheat bran $^{33}$, which diminishes the nitrogen loss as ammonia.

The aqueous seed extract has been traditionally used to purify water in Africa and, in South Asian countries, as a natural coagulant since it has high levels of active cationic proteins with molecular mass between 6 and 16kDa and highly alkaline isoelectric points ${ }^{3,13,46,47}$, with a coagulation efficiency similar to that of alumen in samples with high turbidimetry ${ }^{13}$. Studies have demonstrated low toxicity of this water extract, with a $L_{50}$ value of $512.8 \mathrm{mg} / \mathrm{kg}$ body weight $16,48,49$. This $\mathrm{LD}_{50}$ value is considered to be only moderately toxic when compared with toxicological human standards ${ }^{50}$. In addition, it is known that the seeds are capable of reducing $99.9 \%$ of the bacteria suspended in water after a 1-to-2-hour treatment ${ }^{12}$. The seed powder suspension in concentrations of 30 to $200 \mathrm{mg} / \mathrm{L}$ has been introduced into the Northeast Region of Brazil. Its cultivation has been stimulated in the vicinity of homes for its esthetic beauty, as a fence and to provide shade ${ }^{51}$. All these findings have promoted widespread application of the seeds as a coagulant all over the world, suggesting that the crude extract of. $M$. oleifera seeds can be an alternative for water treatment, especially in developing countries to reduce costs and expand water supplies in rural areas, although no large scale exploitation has yet been performed ${ }^{3}$.

In the state of Ceará (Brazil), approximately $27,000 \mathrm{~km}^{2}$ out of a total area of $148,016 \mathrm{~km}^{2}$ are severely affected by desertification, common in the Northeastern Region of Brazil. Aiming to offer a simple and renewable solution for the deleterious effects of potable water shortage, programs have been created to distribute seeds to rural populations. These programs explore the soil characteristics of the region, improve the people's hygiene habits and quality of life, help reduce child mortality and collaborate with the sustainable development of the region. The population receives Moringa kits with instructions to purify water. The seeds are ground for better efficiency and three ground seeds are added per liter of water $^{51}$.

The roots are less consumed because they contain alkaloids $(0.2 \% \text { of the total })^{1,17}$. Nevertheless, they can be used after grinding as condiments with a hot flavor similar to that of horseradish, reason why $M$. oleifera is also known as the horseradish tree ${ }^{52}$.

\section{O NCLUSION}

The relative lack of antinutritional components and the high protein, lipid and sulfurcontaining amino acid contents encourage the use of Moringa oleifera as animal feed; it is an excellent source of proteins for monogastric animals. The antioxidant action of some compounds present in the plant, one of the most important physiological roles of food, can protect organisms against the deleterious effects of oxidation. Taking into consideration the relative lack of toxic compounds in the seed and its ability to clarify and purify muddy water, the popular dissemination of this plant could constitute an additional food source and an alternative to obtain clean drinking water where it is not available.

\section{A C KNOWLEDGMENTS}

We thank Conselho Nacional de Desenvolvimento Científico e Tecnológico (CNPq), for sponsoring the study (505.773/2004-0 and 501.617/ 2003-5) and for providing a scholarship to Paulo Michel Pinheiro Ferreira.

\section{COLLABORATORS}

P.M.P. FERREIRA was reviewed and wrote the article. D.F. FARIAS helped search references and write 
the article. J.T.A. OLIVEIRA helped search references and organize the review. A.F.U. CARVALHO contributed by suggesting sources and correcting the final version. She also encouraged and accompanied the writing of this review.

\section{REFERENCES}

1. Ramachandran C, Peter KV, Gopalakrishnan PK. Drumstick (Moringa oleifera): a multipurpose Indian vegetable. Econ Bot. 1980; 34(3):276-83.

2. Odee D. Forest biotechnology research in drylands of Kenya: the development of Moringa species. Dryl Biodivers. 1998; 12(3):7-8.

3. Jahn SAA, Musnad HA, Burgstaller $\mathrm{H}$. The tree that purifies water. Cultivating multipurpose Moringaceae in the Sudan. Unasylva. 1986; 38(152):23-8.

4. Oliveira JTA, Silveira SB, Vasconcelos KM, Cavada BS, Moreira RA. Compositional and nutritional attributes of seeds from the multiple purpose tree Moringa oleifera Lamarck. J Sci Food Agric. 1999; 79(6):815-20.

5. Morton JF. The horseradish tree, Moringa pterygosperma (Moringaceae): a boon to arid lands? Econ Bot. 1991; 45(3):318-33.

6. Mehta LK, Balaraman R, Amin AH, Bafna PA, Gulati OD. Effect of fruits of Moringa oleifera on the lipid profile of normaland hypercholesterolaemic rabbits. J Ethnopharmacol. 2003; 86(2-3):191-5.

7. Gilani AH, Aftab K, Suria A, Siddiqui S, Salem R, Siddiqui BS. Pharmacological studies on hypotensive and spasmolytic activities of pure compounds from Moringa oleifera. Phytother Res. 1994; 8(2):87-91.

8. Pal SK, Mukherjee PK, Saha P. Studies on the antiulcer activity of Moringa oleifera leaf extract on gastric ulcer models in rats. Phytother Res. 1995; 9(6):463-5.

9. Farias DF, Brasil ICF, Ferreira PMP, Carvalho AFFU. Potencialidade da vagem de Moringa oleifera Lamarck como cama de animais de laboratório. Rev Univ Rural. 2004; 24(Supl):7-8.

10. Eilert $U$, Wolters $B$, Narsdtedt A. The antibiotic principle of seeds of Moringa oleifera and Moringa stenopetala. Planta Med. 1981; 42(1):55-61.

11. Donli PO, Dauda H. Evaluation of aqueous moringa seed extract as a seed treatment biofungicide for groundnuts. Pest Management Sci. 2003; 59(9):1060-2.

12. Madsen M, Achlundt J, Omer EF. Effect of water coagulation by seeds of Moringa oleifera on bacterial concentrations. J Trop Med Hyg. 1987; 90(3):101-9.
13. Ghebremichael KA, Gunaratna KR, Henriksson $H$, Brumer $H$, Dalhammar G. Simple purification and activity assay of the coagulant protein from Moringa oleifera seed. Water Res. 2005; 39(11): 2338-44

14. Bharali R, Tabassum J, Azad MR. Chemomodulatory effect of Moringa oleifera Lam. on hepatic carcinogen metabolising enzymes, antioxidant parameters and skin papillomagenesis in mice. Asian Pac J Cancer Prev. 2003; 4(2):131-9.

15. Cárceres A, Saraiva A, Rizzio S, Zabala L, De Leon E, Navy F. Pharmacological properties of Moringa oleifera. 2: screening for antispasmodic, antiinflammatory and diuretic activity. J Ethnopharmacol. 1992: 36(3):233-7.

16. Ferreira PMP. Atividade Larvicida do extrato aquoso de Moringa oleifera lamarck contra Aedes aegypti linnaeus: identificação parcial e caracterização bioquímica do princípio ativo [monografia]. Fortaleza: Universidade Federal do Ceará; 2004.

17. Gupta M, Mazumder UK, Chakrabarti S. CNS activities of methanolic extract of Moringa oleifera root in mice. Fitoterapia. 1999; 70(3):244-50.

18. Rangaswani S, Sankarasubramian S. Chemical components of the flowers of Moringa pterygosperma. Curr Sci. 1946; 15:316-17.

19. Jang M, Cai L, Udeani GO, Slwoing KV, Thomas CF, Beecher DM. The red wine phenolics transresveratrol and quercetin block human platelet aggregation in eicosanoid synthesis: implication for protection against coronary heart disease. Clin Chim Acta. 1995; 235(2):207-19.

20. Kawada N, Seki S, Inoue M, Kuroki T. Effect of antioxidants, resveratrol, quercetin, and $\mathrm{N}$-acetylcysteine, on the functions of cultured rat hepatic stellate cells and Kupfer cells. Hepatology (Baltim). 1998; 27(5):1265-74.

21. Abdulla $M$, Gruber P. Role of diet modification in cancer prevention. Biofactors. 2000; 12(1-4): 45-51.

22. Machado DIS, Cervantes JL, Vázquez NJR. Highperformance liquid chromatography method to measure $\alpha$ e $\gamma$-tocopherol in leaves, flowers and fresh beans from Moringa oleifera. J Chromatogr. 2005; 1105(1-2):111-4.

23. Kummar V, Abbas AK, Fausto N, Robbins SL, Cotran RS, editores. Pathology basis of disease. New York: WB Saunders; 2004.

24. Nordberg J, Arnér ESJ. Reactive oxygen species, antioxidants, and the mammalian thioredoxin system. Free Radical Biol Med. 2001; 31(11): 1287-312.

25. Verma SC, Banerji R, Misra G, Nigam SK. Nutritional value of moringa. Curr Sci. 1976; 45(21):769-70. 
26. Dhar B, Gupta OP. Nutritional value of Shigru Moringa oleifera Lam. Bull Med Ethnobot Res. 1982; 3(2-4):280-8.

27. Foidl N, Makkar HPS, Becker K. The Potential of Moringa oleifera for agricultural and industrial uses. Procedings of the 1 th Workshop What Development Potential for Moringa Products? 2001 Oct; Dar es Salaam, Tanzania; 2001.

28. Siddhuraju P, Becker K. Antioxidant properties of various solvent extracts of total phenolic constituents from three different agroclimatic origins of drumstick tree (Moringa oleifera Lam) leaves. J Agric Food Chem. 2003; 51(8):2144-55.

29. Amaya DR, Kerr WE, Godoi HT, Oliveira AL, Silva AR. Moringa: hortaliça arbórea rica em betacaroteno. Hortic Bras. 1992; 10(2):126.

30. Silva AR, Kerr WE, editores. Moringa: uma nova hortaliça para o Brasil. Uberlândia: UFU/DIRIU; 1999.

31. Stephensen $C B$. Vitamin $A$, infection and immune function. Ann Rev Nutr. 2001; 21:167-92.

32. Rao AV, Devi PU, Kamath R. In vivo radioprotective effect of Moringa oleifera leaves. Indian J Exp Pharmacol. 2001; 39(9):858-63.

33. Makkar HPS, Becker K. Nutrients and antiquality factors in different morphological parts of the Moringa oleifera tree. J Agric Sci. 1997; 128(3): 311-22.

34. World Health Organization. Energy and protein requirements. Report of a Join FAO/WHO/UNU Expert Consultation Meeting Series, n.724, Geneva, Switzerland; 1985.

35. Abdulkarim SM, Long K, Lai OM, Muhammad SKS, Ghazali HM. Some physico-chemical properties of Moringa oleifera seed oil extracted using solvent and aqueous enzymatic methods. Food Chem. 2005; 93(2):253-63.

36. Singh $U$, Singh B. Tropical grain legumes as important human food. Econ Bot. 1992; 46(3): 310-2.

37. Vasconcelos IM, Maia AAB, Siebra EA, Oliveira JTA, Carvalho AFFU, Melo VMM, et al. Nutritional study of two Brazilian soybean (Glycine max) cultivars differing in the contents of antinutritional and toxic proteins. J Nutr Biochem. 2001; 12(1):55-62.

38. Food and Drug Administration. Agency response letter. GRAS notice n.000069. Washington (DC): FAO; 2001.

39. Siguel EM, Lerman R. Trans-fatty acid patterns in patients with angiographically documented coronary artery disease. Am J Cardiol. 1993; 71(11):916-20.

40. Tsaknis J, Lalas S, Gergis V, Dourtoglou V, Spiliot V. Characterization of Moringa oleifera variety
Mbololo seed oil of Kenya. J Agric Food Chem. 1999; 47(11):4495-9.

41. Ferrao AMBC, Ferrao MJE. Ácidos gordos em óleo de Moringueiro (Moringa oleifera Lam.). Agron Angolana. 1970; 30(8):3-16.

42. Soliva CR, Kreuzer M, Foid N, Foid G. Feeding value of whole and extracted Moringa oleifera leaves for ruminants and their effects on ruminal fermentation in vitro. Anim Feed Sci Technol. 2005; 118(1-2):47-62.

43. Santos AFS, Argolo ACC, Coelho LCB, Paiva PMG. Detection of water soluble lectin and antioxidant component from Moringa oleifera seeds. Water Res. 2005; 39(6):975-80.

44. Thompson LU. Potential health benefits and problems associated with antinutrients with foods. Food Res Int. 1993; 26(2):131-49.

45. Fish BC, Thompson LU. Lectin tannin interactions and their influence on pancreatic amylase activity and starch digestibility. J Sci Food Agric. 1991; 39(4):727-31.

46. Ndabigengesere A, Narasiah KS, Talbot BG. Active agents and mechanism of coagulation of turbid waters using Moringa oleifera. Water Res. 1995; 29(2):703-10.

47. Okuda T, Baes AU, Nishijima W, Okada M. Improvement of extraction method of coagulation active components from Moringa oleifera seeds. Water Res. 1999; 33(15):3373-8.

48. Berger MR, Habs M, Jahn SAA, Schmahl D. Toxicological assessment of seeds from Moringa oleifera and Moringa stenopetala, two highly efficient primary coagulants for domestic water treatment of tropical raw waters. East Afr Med J. 1984; 61(9):712-6.

49. Grabow WOK, Slabert JL, Morgan WSG, Jahn SAA. Toxicity and mutagenicity evaluation of water coagulated with Moringa oleifera seed preparations using fish, protozoan, bacterial, coliphage, enzyme, and Ames Salmonella assays. Water SA. 1985; 11(1): 9-14.

50. Hodge HC, Sterner JH. Tabulation of toxicity classes. Am Ind Hyg Assoc. 1944; 10(7): 94-7.

51. Gerdes G. Como limpar e tratar água suja com sementes da Moringa. Technical Bulletin. Fortaleza: ESPLAR - Centro de Pesquisa e Assessoria; 1997.

52. Delaveau P, Boiteau P. Huiles à interet pharmacologique, cosmetologique et dietique. Huiles de Moringa oleifera Lam. et de M. Drouhardii Jumelle. Plant Med Phytother. 1980; 14:29-33.

Received on: 14/3/2007

Final version resubmitted on: 13/12/2007 Approved on 8/4//2008 